\title{
Marine resources of the Economic Zone of New Caledonia
}

\author{
Jean-Marie AUZENDE ${ }^{\text {a,f* }}$, René GRANDPERRIN ${ }^{\text {b }}$, Emmanuel BOUNIOT ${ }^{\text {c }}$, Christian HENIN ${ }^{\text {b }}$, \\ Yves LAFOY ${ }^{\mathrm{d}}$, Bertrand RICHER DE FORGES ${ }^{\mathrm{b}}$, Sabrina VAN DE BEUQUE ${ }^{\text {e,f }}$, Sabrina VIRLY ${ }^{\text {b }}$ \\ ${ }^{a}$ Ifremer, DRO/GM/Brest, BP 70, 29280 Plouzané, France \\ ${ }^{b}$ IRD, BP A5, 98848 Nouméa, New Caledonia \\ ${ }^{c}$ Service des méthodes administratives et de l'informatique, BP 8231, Nouméa sud, 98807 Nouméa cedex, New Caledonia \\ ${ }^{d}$ Services des mines et de l'énergie, BP 465, Nouméa, New Caledonia \\ ${ }^{\mathrm{e}}$ Université de Bretagne occidentale, 29200 Brest, France \\ ${ }^{f}$ Present address: Ifremer c/o IRD, BP A5, 98848 Nouméa, New Caledonia
}

Revised 22 March 1999; accepted 4 May 1999

\begin{abstract}
The ZoNéCo programme, devoted to the evaluation of living and non-living marine resources within the Economic Zone of New Caledonia, illustrates clearly the Marine Benthic Habitats concept. It exhibits the study of the physical environment and disciplines such as geology and physical oceanography. The results acquired in these fields are used as bases to study the presence and the distribution of living species within a given habitat. The knowledge of all the parameters relative to each discipline is a useful guide for the evaluation and the sustainable management of living and nonliving resources. (C) 1999 Ifremer / CNRS / IRD / Éditions scientifiques et médicales Elsevier SAS
\end{abstract}

\section{southwest Pacific / New Caledonia / habitat / marine resources}

Résumé - Ressources marines de la zone économique de Nouvelle-Calédonie. Le programme ZoNéCo d'évaluation des ressources marines vivantes et non vivantes de la zone économique de Nouvelle-Calédonie illustre clairement le concept d'hahitat benthique marin. Il implique l'étude du milieu physique et les disciplines telles que la géologie, la géophysique et l'océanographie physique. Les résultats acquis serviront de base à l'étude de la présence et de la répartition des espèces vivantes dans un habitat considéré. La connaissance de l'ensemble des paramètres relatifs à chacune des disciplines est un guide précieux pour l'évaluation et la gestion harmonieuse des ressources. @ 1999 Ifremer / CNRS / IRD / Éditions scientifiques et médicales Elsevier SAS

\section{Sud-Ouest Pacifique / Nouvelle-Calédonie / habitat / ressources marines}

\section{INTRODUCTION}

Following the establishment of the Economic Zones (EZ) in 1979 , many nations undertook programmes aimed at mapping the ocean floor and evaluating their living and non-living resources. In France, at the beginning of the 1980 s, the programme "French Economic Zones" was launched; it was later extended to include France's overseas territories. As with most island nations, these territo- ries have a limited land area compared to the vast size of their EZ, and therefore appear on geographic maps as "maritime giants" even, at global scale, while their landbased resources are scant and their coastal waters are often over-exploited. The territory of New Caledonia was the first of France's overseas territories to express interest in participating in the Economic Zone programme. In November 1990, a Working Group was established and given the task of setting the terms of reference for a pro-

* Correspondence and reprints: auzende@ noumea.IRD.fr 
gramme of study. This programme was named ZoNéCo (for ZoNe éConomique de Nouvelle-Calédonie). The Working Group was composed of 50 scientists and politicians. In 1991 the Working Group precisely defined the basis of the ZoNéCo programme. As with most of the mining prospects, ZoNéCo was divided into three phases:

- A strategic phase, the objective of which was mainly to analyse existing data and the production of seabed topography maps by swath mapping surveys on selected areas.

- A tactical phase, the aim of which was to identify and quantify possible living and non-living resources.

- A third phase named 'target study' devoted to the evaluation of the cconomic potential of these resources.

The programme involves many modern technologies: bathymetry and imagery of the seafloor, gravimetry, magnetism, seismology, satellite altimetry which support physical oceanography, envirommental and fishery sciences. The programme is supported by French research vessels such as Alis of the IRD (Institut de Recherche pour le Développement) and L'Atalante from Ifremer (Institut Français de Recherche pour l'Exploitation de la $\mathrm{Mer}$ ), or foreign ships such as the Tangaroa from Niwa (National Institute of Water and Atmospheric Research Ltd.) in New Zealand. The programme benefits from facilities for processing and archiving data, and for presenting them in formats that are readily accessible to scientists and development agencies.

Thus, ZoNéCo is a multi-disciplinary programme bringing together a number of partners: the French State (Ministère de l'Education Nationale, de la Recherche et de la Technologie; Service Hydrographique et Océanographique de la Marine; Météo-France), the Territory of New Caledonia (SMAI, Service des Méthodes Administratives et de l'Informatique; SME, Service des Mines et de l'Energie; STMMPM, Service Territorial de la Marine Marchande et des Pêches Maritimes), the three Provinces (Islands, North and South), and the locally implanted research institutions (Ifremer; IRD; UFP, Université Française du Pacifique).

\section{TOPOGRAPHY AND NATURE OF THE SEAFLOOR}

Establishing a topographical or bathymetrical map is the first priority for the evaluation of marine resources, as it is for the evaluation of island resources (mining, forestry, farming). Over the last twenty years French and foreign institutions have acquired numerous conventional bathymetric data sets in the EZ of New Caledonia. The compilation and synthesis of these data resulted in the production in 1992 of a map of the whole New Caledonia EZ [17] (figure 1). Although this map is fairly detailed, it is not accurate enough for the purpose of evaluating marine resources.

The first objective of the ZoNéCo programme was to select from this map areas of priority for accurate swath mapping surveys. Mapping of these priority areas was made possible by the installation on board the R.V. L'Atalante of an EM 12 Dual multibeam echosounder, which has far greater abilities than conventional equipment in terms of accuracy and area coverage. This system is capable of surveying an area seven times wider than the depth of water; for example at a depth of $3000 \mathrm{~m}$, a swath $20 \mathrm{~km}$ wide can be covered (figure 2).

The EM 12 Dual echosounder can be imaged to produce shaded relief maps and also collects acoustic reflectivity of the seabed. The intensity of the reflectivity is a function of the nature of the bottom. For example, a soft sedimentary cover provides a light-coloured image, while a rocky bottom produces dark shading of high contrast that varies from dark grey to black. Because knowledge of the seafloor is based on remote observations, the next step in the programme will be to ground truth the bathymetric data to confirm and calibrate the interpretation of the acoustic images recorded by the sounder. The data recorded by the EM 12 Dual multibeam echosounder can also be used to produce three-dimensional representations, making it particularly easy to visualise the topography and nature of the ocean floor.

To improve upon the knowledge of the topography of the selected areas, four cruises were carried out onboard the R.V. L'Atalante between 1993 and 1996. In addition to the bathymetric coverage, single channel seismic profile, magnetic and gravity data were acquired during these surveys. Also during these cruises, current measurements obtained with a Acoustic Doppler Current Profiler (ADCP) and Expendable Bathythermograph (XBT) casts were collected in the water column between 0 and $800 \mathrm{~m}$ depth. These measurements were made simultaneously to surface thermo-salinity recordings. The results of the four cruises are summarized in figure 3 and as follows:

- ZoNéCo 1 cruise (25 June-15 July 1993) surveyed the southern prolongation of New Caledonia and Loyalty Islands characterized by two parallel ridges culminating 


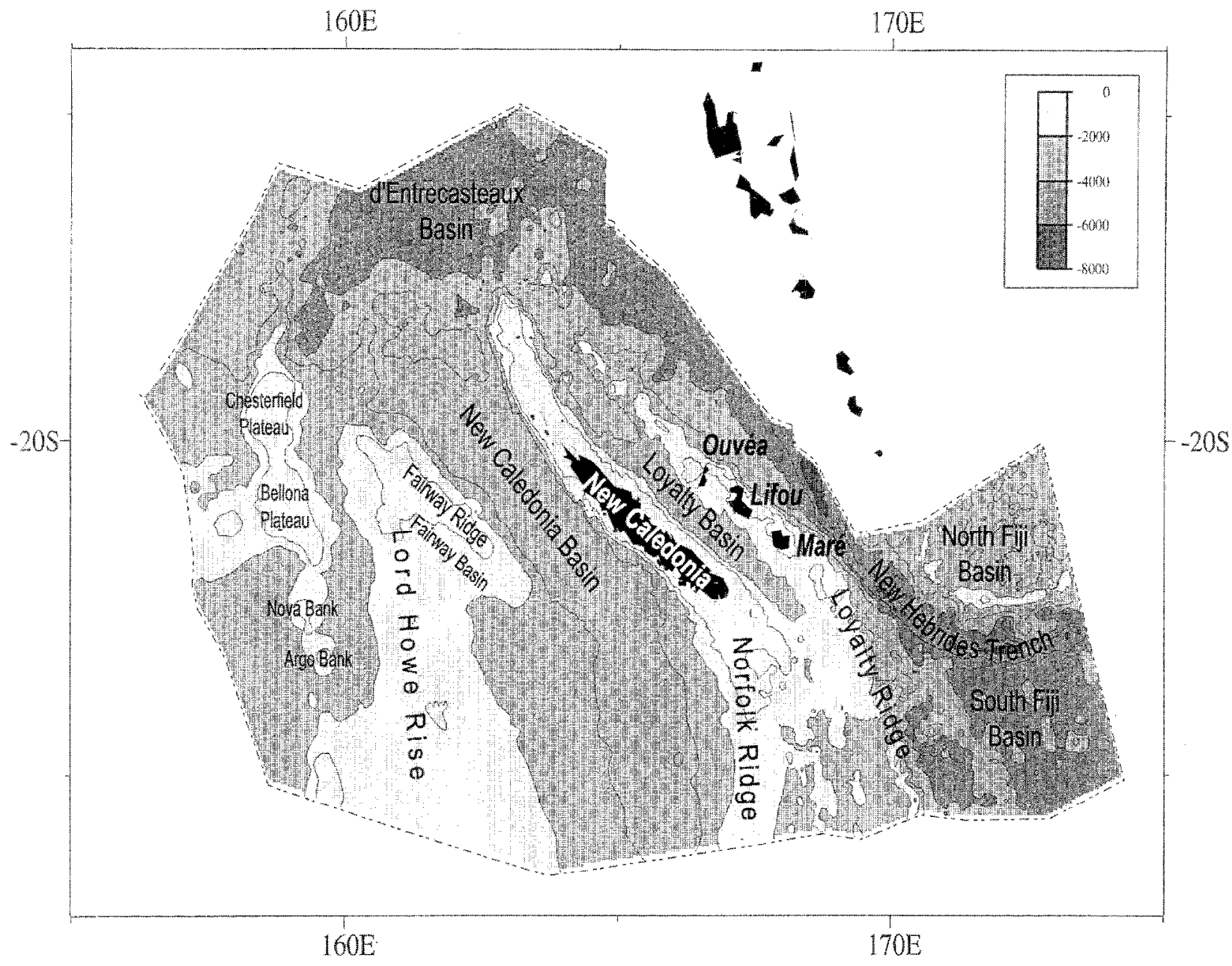

Figure 1. 'loponymic and bathymetric map of the 200 mile EZ of New Caledonia. Located between latitudes $15^{\circ}-20^{\circ} \mathrm{S}$ and longitudes $156^{\circ}-174^{\circ} \mathrm{E}$, it lies at the eastern edge of the Australian lithospheric plate and extends over an area of about 1.4 million square kilometres (after Missègue et al. [17]).

at a depth of less than $1000 \mathrm{~m}$. Due to their steep slopes, these ridges are devoid of sedimentary cover. This is especially the case with regard to the sharp volcanic features superimposed on the flat-topped elongated ridges constituting the main architecture of the region $[9,19]$.

- ZoNéCo 2 cruise (2-22 August 1994) surveyed Le Grand Passage and the area between New Caledonia and the Loyalty Islands. Le Grand Passage is the area, north of New Caledonia that is characterized by shallow waters (less than $500 \mathrm{~m}$ ) and by a sedimentary-covered flat area that represents the surface of an ancient deep sedimentary basin. This basin was uplifted during the Tertiary compressive phase that resulted from the obduction of the New Caledonia ophiolites $[2,9,10,11,16]$.
- ZoNéCo 3 cruise (28 August -16 September 1996) surveyed the shallow waters $(50-350 \mathrm{~m})$ around the Loyalty Islands with the EM 950 and the areas betwecn those areas surveyed during ZoNéCo 1 and ZoNéCo 2 [18].

- ZoNéCo 4 cruise (18 September-12 October 1996) surveyed, using the EM 12 Dual and the EM 950, the Fairway Ridge, the Chesterfield-Bellona Plateau and the Lord Howe Rise all located west of the main island of New Caledonia. The Fairway Ridge and the Lord Howe Rise are respectively a piece of oceanic crust and a continental block, capped by coral reefs and uplifted during the Tertiary compressive phase $[2,15,16,18]$.

$\Lambda t$ the same time as the ZoNéCo cruises, the MOP (Mission Océanographique du Pacifique), hydographic 


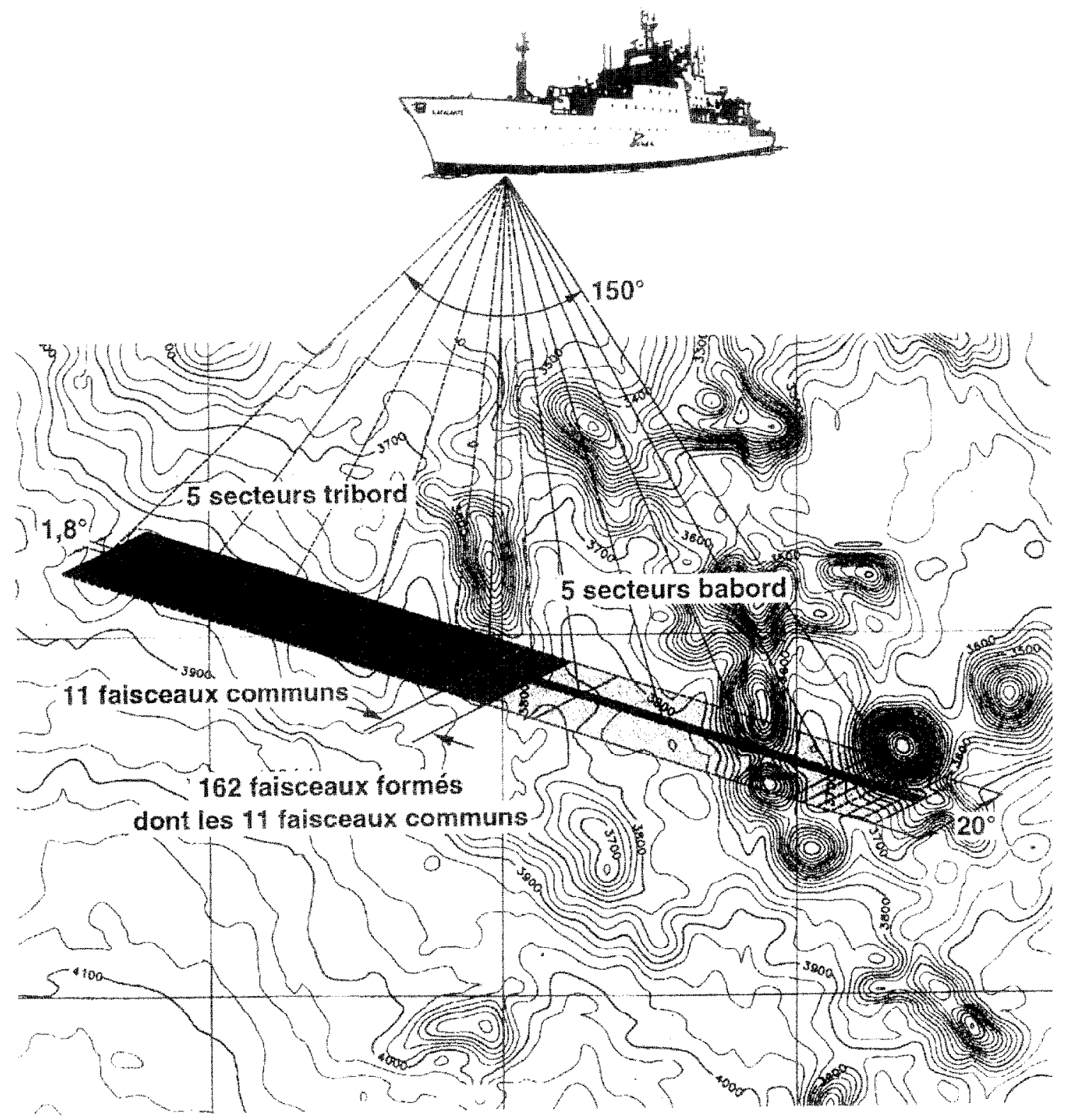

Figure 2. The EM 12 Dual multibeam echosounder ( 150 beams at one degree each) which provides simultaneously bathymetry and imagery of the seafloor and operates in water depths ranging from 100 to $11000 \mathrm{~m}$. It covers up to about seven times the water depth, e.g. a $20 \mathrm{~km}-$ wide strip in one pass at a depth of $3000 \mathrm{~m}$

branch of the French Navy carried out a complementary bathymetric survey in the shallow areas around the $L e$ Grand Passage and the Loyalty Islands using the R.V. Laplace. This was a very detailed survey that extended into very shallow areas. All the data acquired by R.V. L'Atalante and R.V. Laplace have been merged, processed and stored by the processing department of the ZoNéCo programme.

\section{THE CLIMATIC AND HYDROLOGICAL ENVIRONMENT}

During the seabed surveys carried out by R.V.L'Atalante, physical oceanography measurements were also obtained $[7,8]$. XBT casts provided sea water temperature profiles down to $700 \mathrm{~m}$, ADCP profiles provided measurements of absolute current velocities within the $0-700 \mathrm{~m}$ 


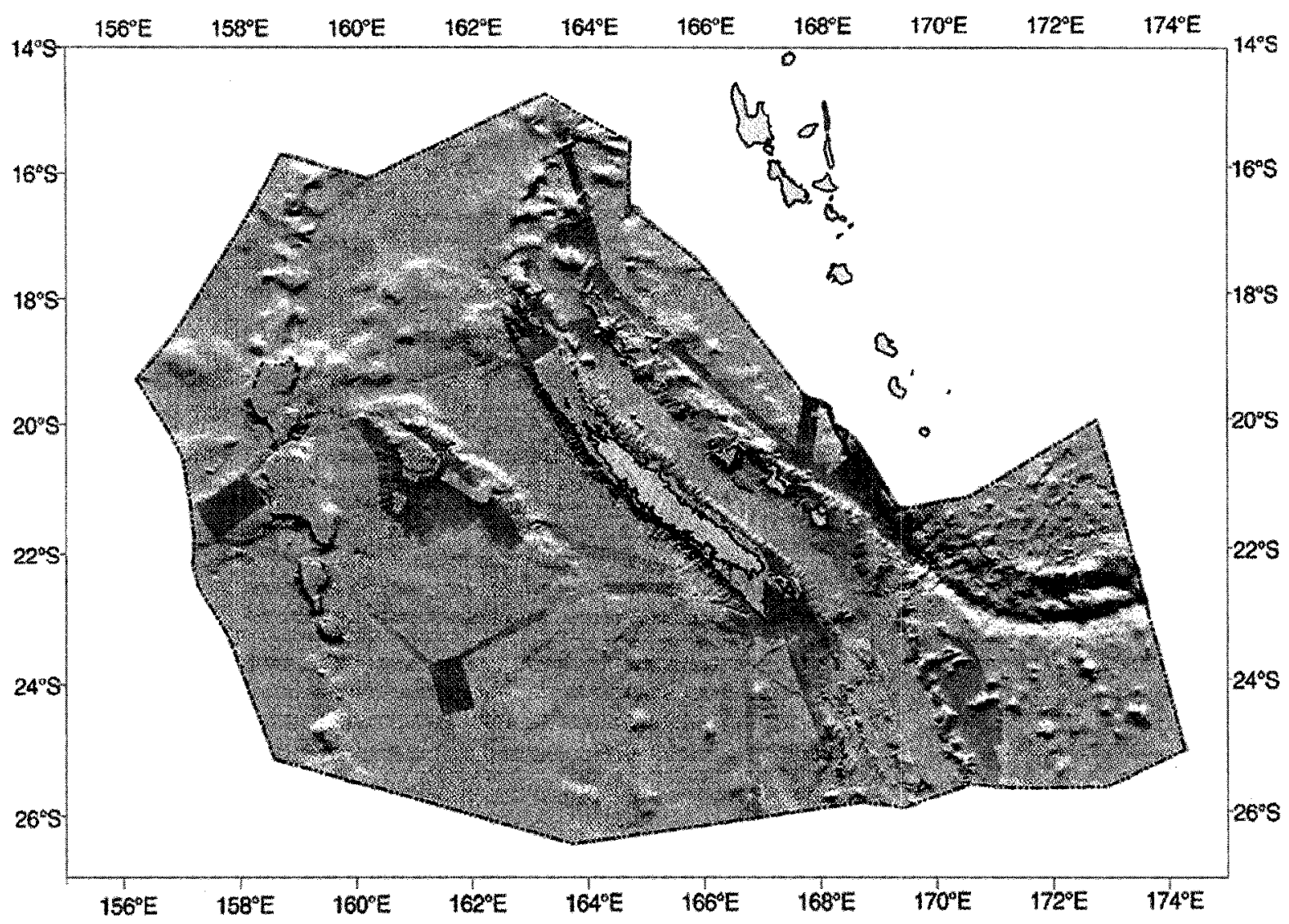

Figure 3. Bathymetry of the New Caledonia EZ. In colour: multibeam bathymetry data acquired during the ZoNéCo cruises 1 to 4 . Shaded: conventional bathymetric data acquired before the ZoNéCo programme.

depth layer and thermosalinographs recorded surface temperature and sallinity. In addition, routine meteorological observations were made every three hours. Analysis of the data acquired resulted in some interesting findings. The first was evidence for the existence of powerful currents in specific areas, such as a large $(200 \mathrm{~km}$ diameter) deep counter-clockwise gyre southeast of the main island of New Caledonia, first observed in July 1993 [7] that extended from the surface down to a depth of $700 \mathrm{~m}$ (figure 4). This gyre may play a major role in the dissemination of the larvae and juveniles of marine species of commercial interest [14]. Another important result was the confirmation of the existence of significant sea surface temperature and salinity differences between the eastern and the western parts of New Caledonia. A third result was the detection of low-salinity warm waters coming from the north, and of cold waters coming from the south; well-defined surface temperature and salinity fronts were thus observed south of the Isle of Pines.
As part of the programme, ZoNéCo oceanographic observation networks have been established both onshore at fixed stations and offshore on the many merchant ships that cross the zone and participate in the Ship Of Opportunity Programme (SOOP). The merchant ships that participate are equipped with surface thermosalinographs and XBT launching system for the measurement of sea surface temperature and salinity, and the recording of temperature profiles down to a depth of $700 \mathrm{~m}$. The data collected during the programme showed the impact of the El Niño phenomenon on the New Caledonia region, where it had a significant influence on climatic and oceanographic conditions (drought, increase of surfacewater salinity and cooling of water). These data also showed upwelling along the southwestern coast of the main island, which was linked to wind conditions. This is likely to have an influence on the distribution of marine species of commercial interest, and needs continued study. 


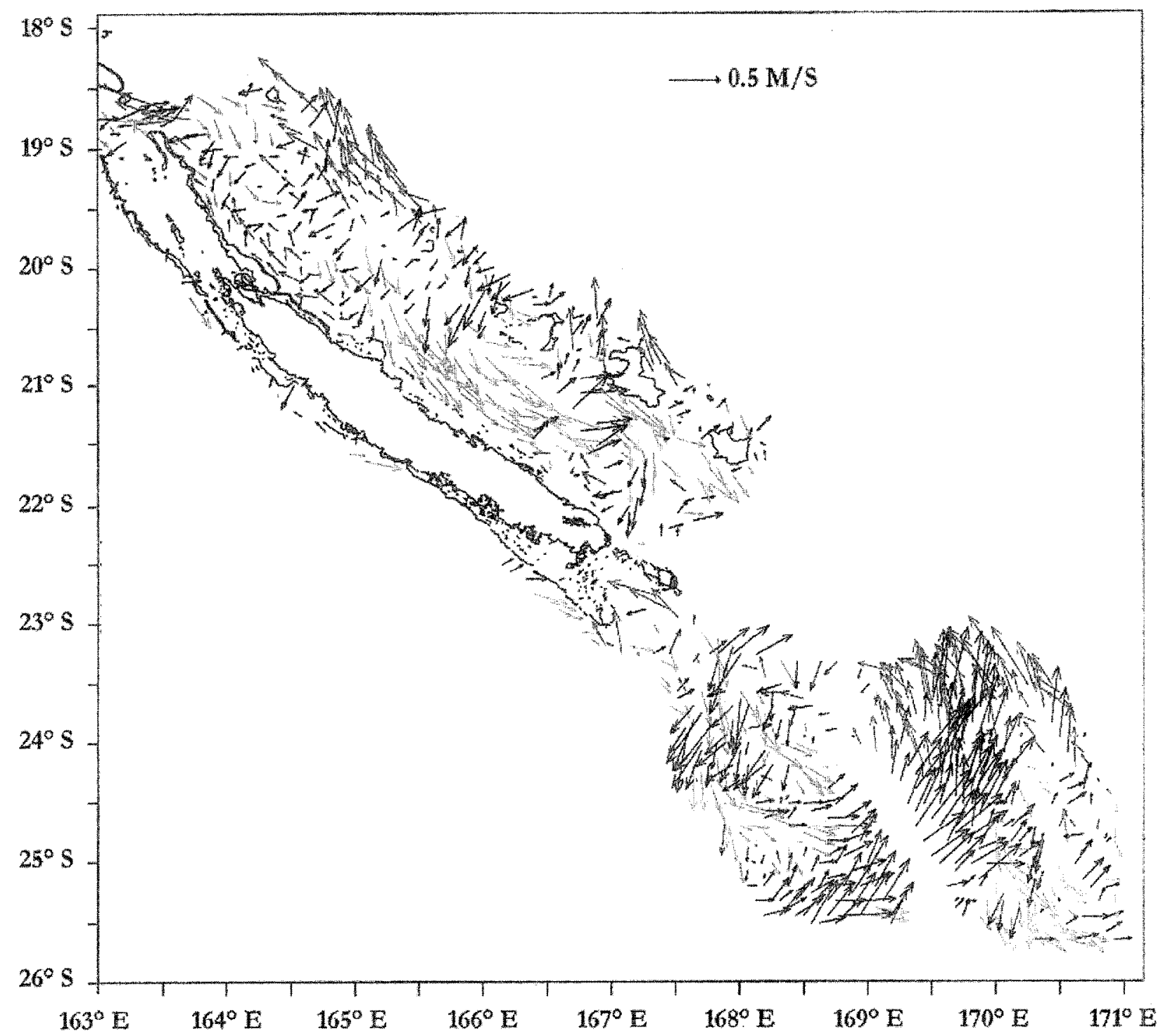

Figure 4. Mean currents in the 28-100 m layer. Top: the observations made during the ZoNéCo 2 cruise in August 1994 confirm the coastal current (Vauban Current) hypothesis along the east coast of New Caledonia. Bottom: a deep energetic counter-clockwise gyre was observed in the southeast of the EZ during the ZoNéCo 1 cruise in July 1993 (after Hénin [8]).

\section{MINERAL RESOURCES}

The major non-living resources thought to exist in New Caledonian waters are polymetallic crusts and hydrocarbons as well as possible phosphates, which represent a major resource for certain nations of the western Pacific such as Nauru.

Polymetallic crusts are most usually formed at the summits of topographical structures such as seamounts or submerged terraces. In New Caledonia, seamounts have been identified and sampled along the western edge of the Norfolk Ridge, east of the Loyalty Islands and in the area of the d'Entrecasteaux reefs. Analysis of dredged samples revealed the presence of cobalt, in reasonable concentrations, and of traces of precious metals such as gold, silver and platinium. Research in this field is just beginning, and further investigations are needed, particularly on the ridges and seamounts that were mapped during the surveys carried out by R.V. L'Atalante. A report [12] summarizes all the known data concerning these resources. 


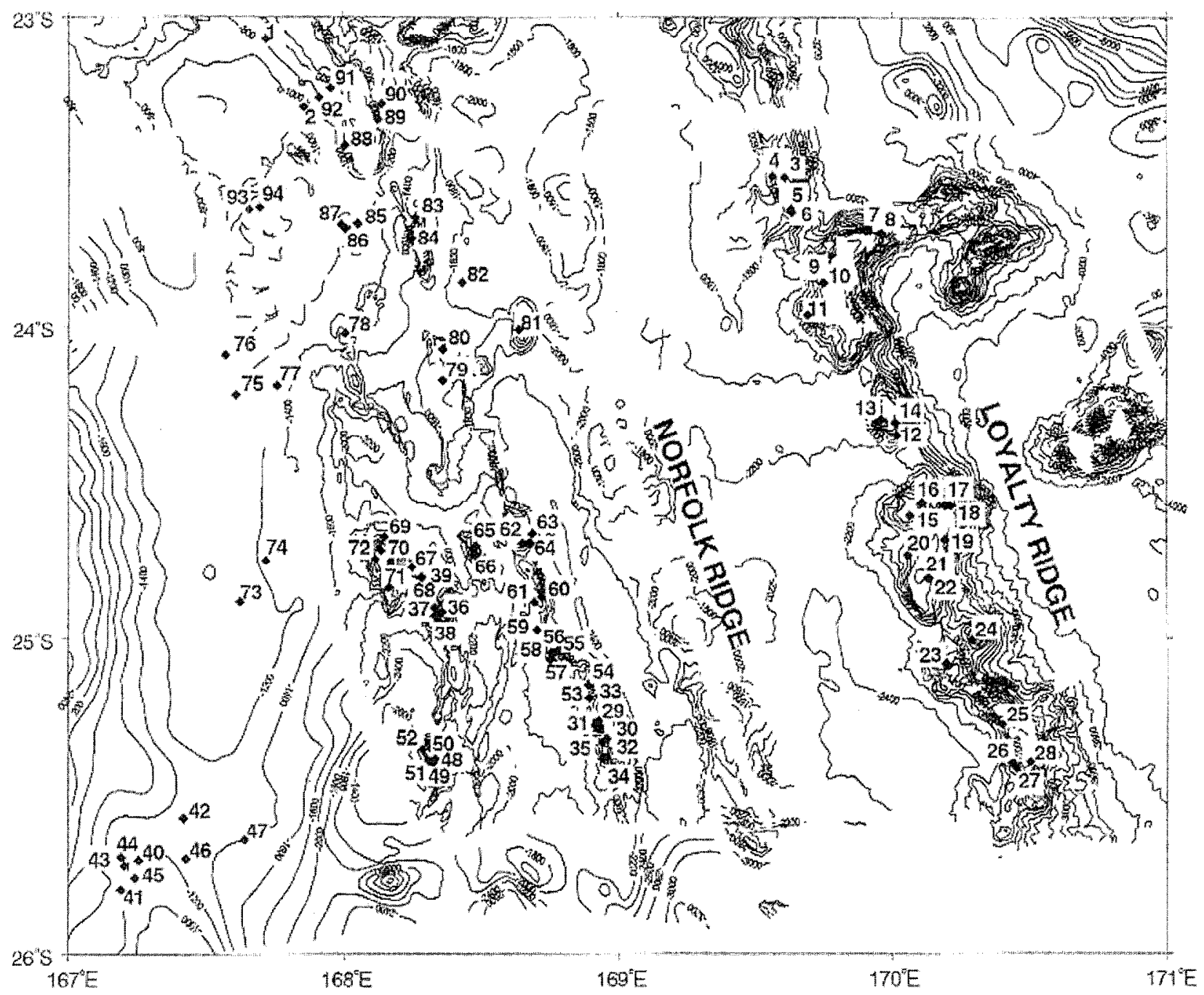

Figure 5. Localion map of the trawling stations completed onboard Tangaroa on the Norfolk Ridge and on the southern prolongation of the Loyalty Ridge (after Grandperrin [6]).

Regarding hydrocarbons, seismic investigations carried out by various oil companies during the 1970s showed that the lagoon of the main island of New Caledonia, the Chesterfield Plateau and Le Grand Passage are potential sites for oil exploration. Using seismic profiles recorded along the Lord Howe Rise, at the southern limit of New Caledonian waters, Australian scientists from AGSO (Australian Geological Survey Organisation) and French Scientists from. Ifremer and Insu (Institut National des Sciences de l'Univers) and New Caledonian geologists described a large area showing promising potential for gas hydrates and oil exploration $[1,20]$. A joint programme named the Faust Programme, linked with
ZoNéCo Programme was recently installed for the study of the area.

A report [13] summarizes current knowledge about oil potential onshore and offshore. This report shows that research in offshore areas is needed to adequately define hydrocarbon potential. However, promising areas have been identified in the Bourail Zone onshore, within the western, northern and southern lagoons and offshore in Le Grand Passage Zone and on the Chesterfield-Bellona Plateau.

The assessment of the different mineral resources is still too fragmentary to reach conclusions about commercial potential in the New Caledonia region. To undertake a 
comprehensive study further sampling and geophysical investigation is necessary. Sampling and geophysical cruises are planned for the second stage of the ZoNéCo programme which will focus on ridges and seamounts at depths of less than $1500 \mathrm{~m}$ due to the technical limits of commercial exploitation.

\section{LIVING RESOURCES}

\subsection{Existing data}

Prior to the beginning of the ZoNéCo programme, a large amount of data concerning fisheries had been collected over a span of several years. These data were awkward to use, as they were presented and stored in a variety of formats (fishing log sheets, various printed reports, computerized records in a variety of incompatible software formats, etc.), and scattered among different territorial and provincial fisheries departments, both in national and external (Korea, Taiwan, Japan) research institutions and international scientific bodies (SPC). To make this information more readily available to potential users, the ZoNéCo programme regrouped and synthesised these data into two coherent documents. The first document [21] was devoted to tuna and associated species (swordfish, marlin, mahi-mahi). The inter-annual, seasonal and geographical fluctuations of fishing activity and production are described. The second document [22] concerns deep species of commercial interest (fish, crustaceans and molluscs) which are caught using reels, deep bottomlines, trawls and traps between depths of 100 and $1500 \mathrm{~m}$. Fluctuations of catch related to fishing method, geographical location and habitats (depth, seabed structure, water circulation) are described. The part played by this fishing industry in New Caledonia is discussed in the document. All the data used in the completion of these two documents have been transferred to the ZoNéCo fisheries database.

\subsection{Exploratory fishing surveys}

In 1994 and 1995, the R.V. Alis carried out two exploratory surveys devoted to deep bottom-longline fishing $(300-800 \mathrm{~m})$ in the area north of the main island of New Caledonia and on the Loyalty Ridge [3, 4]. Sixty species of fish were caught. The following significant parameters were noted: presence of large size deep-water red snapper (Etelis spp.) found down to $600 \mathrm{~m}$ where they represent a brood stock beyond the reach of fishermen; the presence of alfonsino (Beryx splendens), a commercially exploitable species, sparsely distributed throughout the explored area at depths ranging from 500 to $800 \mathrm{~m}$; abundance of black bream (Eumegistus illustris), a species not yet discovered by consumers and of good potential for the artisanal fishery sector; presence of numerous species of small edible sharks, whose livers are particularly rich in squalene.

Two other surveys investigated the deep resources by trawling. One was carried out in 1994 by the R.V. Alis along the east coast and to the south of New Caledonia [5]. The cruise used three different trawls operating between 200 and $1200 \mathrm{~m}$. From the scientific point of view, this cruise was a success due to the use of different types of gear leading to the capture of a large number of species of fish and invertebrates, many of them new to science. Over 180 species of fish were captured and are listed in the cruise reports [5]. From the resource point of view, the fishing effort was more disappointing, showing no significant commercial stocks exploitable by trawling off the east coast. Trawls on the southwestern submarine slopes, however, proved richer, with the presence of potentially exploitable species of fish and prawn. The second exploratory trawling survey [6] was undertaken in 1996 by the Tangaroa (figure 5), the New Zealand research vessel owned by Niwa. Seventeen scientists were on board, representing the three Provinces, Ifremer, Orstom, and research institutions from New Zealand, Great Britain and the United States. Hauls were made at depths ranging from 230 to $1860 \mathrm{~m}$, mostly on the seamounts of the Norfolk Ridge, the southern end of the Loyalty Ridge and part of the Lord Howe Rise. In total, 275 species of fish belonging to 101 families were caught, including many new to science. In particular 42 species of shark and ray were collected of which $40 \%$ are new to science. The catches confirmed the presence of Beryx splendens on the summit of some seamounts. The trawls, however, failed to bring up any specimens of orange roughy (Hoplostethus atlanticus), in spite of the fact that this species is abundant further south, in the New Zealand part of the Norfolk Ridge, where it is the target of a flourishing fishing industry.

These exploratory surveys collected a particularly rich and diverse fauna, with a high proportion of endemic species, often of an archaic character. Many specimens of fish and invertebrates were given to specialists for taxonomic identification and studies. Specimens of alfonsino were kept for later genetic studies aimed at establishing whether they belong to a single or to several stocks; a bet- 
ter understanding of this particular parameter is fundamental in the formulation of resource management rules.

\section{DATA STORAGE: THE LOCAL MANAGEMENT AND PRACTICAL APPLICATIONS DEPARTMENT}

The ZoNéCo programme has developed its own computer facility, named SGVL (Structure de Gestion et de Valorisation Iocale). Its role is the archiving, processing, analysis and distribution of the data and results generated by ZoNéCo. The SGVL has both hardware (desktop computers, SUN workstations, large-size tracing tables) and state-of-the-art software compatible with the latest computer equipment used by its research partners.

The SGVL is in charge of collecting, compiling and archiving of the data obtained prior to the ZoNéCo programme and during the ZoNéCo cruises.

The SGVL is also in charge of the distribution of the processed data (synthetic reports, thematic maps, atlases, CD-ROMs) to the partners of the programme, the scientific community and socio-professionals. The databases are regularly updated, and constitute a vast store of knowledge on the evolution of the physical environment and the habitat condition of the resources.

\section{CONCLUSION}

New Caledonia is located on the edge of the world's largest concentration of warm water, known as the "warm pool'. The results obtained during ZoNéCo surveys concerning the physical oceanography parameters contribute to a description of the seasonal and inter-annual variability of climate and rainfall conditions throughout the region (El Niño Southern Oscillation-Enso). The knowledge of these parameters is of a major economic interest in terms of abundance of exploited fish such as tuna, the largest captures of which are made in the equatorial western Pacific.

The study of samples of commercially exploitable deepsea species collected during the programme, particularly alfonsino, has greatly benefited from the knowledge of the physical parameters and the geological structures defining such a large scale habitat. The ZoNéCo database, particularly its habitat component, can be consid- ered as the first step toward the establishment of a fishing and aquaculture monitoring facility, a tool which is increasingly being seen as indispensable in New Caledonia.

The specimen collections covering the New Caledonia EZ and its surrounding region are unique in their thoroughness and quality. These data have revolutionised our understanding of the biodiversity of the bathyal fauna and its relationship with the habitat. In addition, the bathyal samples taken during the ZoNéCo cruises gave an idea of the distributions of organisms (echinoderms, sponges and ascidians) already known for containing pharmacologically active molecules, which are pigments, alcaloides and steroides. Some of them are studied for use against cancerous tumors and the HIV virus, others are studied for their antibiotic, antifouling or insecticid properties.

The ZoNéCo programme represents an original integrated' approach, involving at the same time government decision makers at the central, territorial and provincial levels, and research scientists. The programme is designed to have a limited duration, and should soon result in practical applications for both the public and private sectors. The programme is readily exportable to the majority of small tropical island nations.

Regarding commercial fishing, most shallow coastal waters are increasingly being overexploited due to the alarming rise in population; most island nations are intent on identifying new fishing resources in the short term. Their immediate concern is to generate employment, to stem the urban migration, to establish commercial distribution circuits, and to encourage the consumption of local products in order to reduce their dependence on imports. With this in mind, they are turning to offshore fishing, targeting mainly tuna and the deep bottom species that dwell on the outer reef slopes and seamounts. In this context, programmes such as 'LoNéCo are extremely valuable tools in the search for and sustainability of new exploitable living resources.

\section{Acknowledgement}

The authors thank the ZoNéCo Programme for its financial and logistic support. They thank the anonymous referees in their fruitful comments and their help in improving the English text. 
[1] Auzende I.-M., Projet Faust (Гrench-Australian Seismic Transect): premier transect de sismique multitraces entre l'extrémité méridionale du bassin Nord fidjien et la marge orientale australienne, Géochronique, 67, 1998, pp. 5-6.

[2] Dubois J., Launay J., Récy J., Uplift movements in New Caledonia-Loyalty Islands area and their plate tectonics interpretation, Tectonophysics 24 (1-2) (1974) 133-150.

[3] Grandperris R., Bargibant G., Menou J.-L., Campagne Halical 1 de pêche à la palangre de fond dans le nord et sur la ride des Loyauté, en Nouvelle-Calédonie, N.O. Alis, 21 nov.$1^{\text {er }}$ déc. et 12-23 déc. 1994, rapport final, Nouméa : Orstom, Conv. Sci. Mer, Biol. mar. (Convention Orstom/Programme ZoNéCo, Convention particulière 1994), 12 (1995a) 67 p.

[4] Grandperrin R., Menou J.-L., Bargibant G., Hoffschir C., Le Vaillant T., Campagne Halical 2 de pêche à la palangre de fond dans le nord et sur la ride des Loyauté, en Nouvelle-Calédonie, N.O. Alis, 17-27 janv. et 1-17 fév. 1995. Nouméa : Orstom, Conv. Sci. Mer, Biol. mar. (Convention Orstom/Programme ZoNéCo, Convention particulière 1995) (1995b) 13, 48 p.

[5] Grandperrin R., Bujan S., Menou J.-L., Richer de Forges B., Rivaton J., Campagne Halipro 1 de chalutages exploratoires dans l'est et dans le sud de la Nouvelle-Calédonie (N.O. Alis, 18-25 mars et 29 mars-1 ${ }^{\text {er }}$ avril 1994), Nouméa : Orstom, Conv. Sci. Mer, Biol. mar. (Convention Orstom/Programme ZoNéCo, Convention particulière 1994) 14 (1995c) 61 p.

[6] Grandperrin R., Farman R., Lorance P., Jomessy T., Hamel P., Laboute P., Labrosse P., Richer de Forges B., Seret B., Virly S., Campagne Halipro 2 de chalutages exploratoires profonds dans le sud de la zone économique de Nouvelle-Calédonie (R.V. Tangaroa, 4-28 novembre 1996), Programme ZoNéCo, $1997,150 \mathrm{p}$

[7] Hénin C., Rapport des donuées physiques de la campagne ZoNéCo 1 à bord du N.O. L'Atalante du 26 juin au 15 juil. 1993, Nouméa : Orstom, Rapp. Missions, Sci. Mer, Océanographie, 11, 1994, $62 \mathrm{p}$.

[8] Hénin C., Gallois F., Langlade M.-J., Water Masses and Currents observed in the Exclusive Economic Zone of New-Caledonia, XVIII Pacific Science Congress, June 5-12, 1995, Beijing, China (Poster).

[9] Lachaud D., Structure et évolution géodynamique de l'ensemble ride des Loyauté, bassin des Loyauté, ride de NouvelleCalédonie, 1995, DEA univ. Bretagne occidentale, 1995, 49 p.

[10] Lafoy Y., Pelletier B., Auzende J.-M., Missegue F., Mollard L., Tectonique compressive sur les rides de Fairway et Lord Howe, entre Nouvelle-Calédonie et Australie, C.R. Acad. Sci., Paris, 319, Série II (1994) 1063-1069.

[11] Lafoy Y. Missegue F., Cluzel D., Lachaud D., Rapport final de la campagne ZoNéCo 2, groupe de projet ZoNéCo, n² 2, 1995 , $136 \mathrm{p}$.
[12] Lafoy Y., Van de Beuque S., Perrier J., Auzende J.-M., Bilan des connaissances sur les potentialités en ressources minérales profondes de la zone économique exclusive de NouvelleCalédonie, Programme ZoNéCo, 1996a, 71 p.

[13] Lafoy Y., Auzende J.-M., Missègue F., Van de Beuque S., Bilan des connaissances sur l'évaluation du potentiel pêtrolier de la Nouvelle-Calédonie et de ses dépendances, Programme 7 oNéCo, 1996h, 72 p.

[14] Lehodey P., Grandperrin R., Marchal P., Reproductive biology of a deep demersal fish, alfonsino, Beryx splendens, over seamounts of New Caledonia, Mar. Biol. 128, 1 (1997) 17-27.

[15] Le Suavé R., Lafoy Y., Missègue F., Moreau D., Laporte C., Van de Beuque S., Virly S., Lericolais G., Le Drezen E., Normand A., Saget P., Cornec J., Pinguet F., Perrier J., Join Y., Pau M.E., Vaillant D., Renaud Y., Gueguen B., Nicolas C., Quinquis R., Rapport de mission ZoNéCo 4. Programme ZoNéCo, 1996, 225 p.

[16] Mignot A., Sismo-stratigraphie de la terminaison nord de la ride de Lord Howe. Évolution géodynamique du Sud-Ouest Pacifique entre l'Australie et la Noúvelle-Calédonie, doct. $3^{\mathrm{e}}$ cycle, univ. Pierre-et-Marie-Curie, Paris, 1984, 205 p.

[17] Missègue F., Dupont J., Daniel J., Carte bathymétrique de synthèse de la zone économique de la Nouvelle-Calédonie, Projet ZOE 500, rapport de fin d'exécution des travaux, Nouméa : Orstom, Conv. Sci. Terre, Géologie-Géophysique, 5 (1992) 44 p. et annexes.

[18] Missègue F., Lafoy Y., Le Suavé R., Van de Beuque S., Desrus M., Clouard V., Grandperrin R., Voisset M., Le Drezen E., Normand A., Saget P., Perrier J., Cornec J., Audoine E., Vaillant D., Le Philippe J.-L., Lossouarn H., Schramm J.M., Coquet S., Le Doare J., Quinquis R., Rapport de campagne ZoNéCo 3 (30 août au 20 sept. 1996), Programme ZoNéCo, $1996,226 \mathrm{p}$.

[19] Pautot G., Lafoy Y., Dupont J., Grandperrin R., Henin C., and scientific party on board L'Atalante, Morphostructural study of the southern end of New Caledonia and the Loyalty Ridge: Preliminary results of the ZoNéco 1 cruise, SOPAC Miscellaneous Report, 1993, p 8-10.

[20] Van de Beuque S., Auzende J-M., Laroy Y., Nercessian A., Régnier M., Bernardel G., Symonds P., Exon N., Transect sismique continu entre l'Arc des Nouvelles-Hébrides et la marge orientale de 1'Australie : Programme Faust (French-Australian Seismic Transect), C.R. Acad. Sci. Paris 327 (1998) 761-768.

[21] Virly S., Synthèse halieutique des données thonières de la zone économique de Nouvelle-Calédonie (1956-1994) Programme ZoNéCo, 1996, $215 \mathrm{p}$.

[22] Virly S., Les pêches profondes réalisées dans la zone économique de Nouvelle-Calédonie : synthèse des données de 1970 à 1995, Programme ZoNéCo, 1997, 224 p. 